\title{
Multiple Dimensions of Gender (Dis)Parity: A County-Scale Analysis of Occupational Attainment in the USA, 2019
}

\author{
Madhuri Sharma
}

Citation: Sharma, M. Multiple Dimensions of Gender (Dis)Parity: A County-Scale Analysis of Occupational Attainment in the USA, 2019. Sustainability 2021, 13, 8915. https://doi.org/10.3390/su13168915

Academic Editors: Carlos Ferrás Sexto, Barney Warf and Rubén C. Lois-González iations.

Department of Geography, University of Tennessee, Knoxville, TN 37996-0925, USA; msharma3@utk.edu; Tel.: +1-865-974-6077

\begin{abstract}
Gender economic parity comprises an integral part of the United Nation's 17 goals toward attaining sustainable development. Women have historically been confined to feminine occupations associated with lower pay, which have negatively impacted their economic wellbeing. This paper examines gendered dimensions of occupational (dis)parity across US counties and their association with educational attainment. Drawing on five years' American Community Survey estimates (2015-2019) data from the National Historical Geographic Information System, I conduct descriptive statistical analysis of occupation-based location quotients and education, followed by an in-depth share analysis of 26 gender-based sub-categories of occupations. The correlation analysis provides insights into the multiple dimensions of gendered inequalities. Women's largest engagements still include sales/office (28.66\%), service (21.15\%), and education/legal/communityservice/arts/media (15.03\%) - accounting toward $65 \%$ of all employed women in the US. Women majoring in science/engineering and related disciplines are still the lowest, which manifests into their alarmingly lower representations in science/engineering and related occupations. This suggests strategic policy interventions to advance women in STEM education. This analysis, however, also suggests occupational parity for women with a master's education and above who share almost similar types of relationships with major categories of occupations, even though the coefficients are more favorable for males in managerial jobs.
\end{abstract}

Keywords: gender economic disparity; United Nations; sustainable development; gendered dimensions; American Community Survey; location quotients; share analysis; correlation analysis; science/engineering; STEM education

\section{Introduction}

Gender remains a significant part of a household, family, and society at large, yet the scholarship on measuring multiple dimensions of gendered inequalities has remained rather shallow. While economic geography literature has generally attempted to provide a global and regional overview of gendered dimensions in occupation, industry, employment, and the like, very little has been done to dig deeper into the microscopic measures of disparities across occupation types at finer scales of geography [1]. The reasons for relatively less focus on detailed and fine-scale analysis of gendered dimensions of inequalities have been lack of specificity in analyzing and understanding the spatial variations of gender economy, lack of wholesome high-quality data at one source, and the difficulties and time-consuming task of gleaning gender-based data from a variety of scattered sources that make it tedious and unappealing to many feminist scholars and social scientists [2].

This research analyzes disparity in gendered dimensions of occupations across the counties of the USA to capture the regional and sub-regional nuanced variations in these patterns. In doing so, this paper likens these occupational variations with gendered dimensions of educational attainments to holistically situate these patterns from the Human Capital Theory perspective, using educational attainments as a proxy for human capital. In this paper, I use the 2015-2019 five-year estimate data from the American Community 
Survey provided by the NHGIS (National Historical Geographic Information System) of the Minnesota Population Center. I use the county scale data (the reasons for choosing county as a scale of analysis are detailed in the research design section) across the USA to compute and map the location quotients for major types of occupations to gain insights into the gendered dimensions of (dis)parities. Additional statistical investigative methods are used to draw detailed share analysis and relational contexts of gender-based patterns for the 26 sub-categories of occupations in the US.

\section{Brief Overview of Gendered Economic Inequalities}

\subsection{Post-Fordism and the Origin of Gender Disparity}

The history of economic inequalities has complicated overlaps with changing economy and industry structure in the US, dating back to the World War II era. Although 1947 to 1975 was usually known as the most prosperous time in the American history, especially for economic prosperity and redistribution, the scenario has changed dramatically since the 1970s-the post-Fordist era-and the demise of the middle-class has continued to date, with the bottom 20 percent of the nation's population seeing their income grow far slower compared to those in the top 5 percent [3]. Scholars have indicated that the post-Fordist society has been responsible for creating increasingly less egalitarian social relationships that have been unfavorable to minorities and women, as well as single women with children [4-7]. The post-Fordist economy has bifurcated deep trenches between those employed in very high-paying jobs that require considerable investment in education and human capital and those in low-paying jobs that require lower skills, a large majority of which are performed by minorities and women [1,8-10]. Thus, while the fruits of post-Fordism were and still are being enjoyed by the skilled, educated, and the smarter and talented lots in larger society, those with lower educational attainments have been left behind, and these have indeed created enormous differences in individuals' earning potentials [11-14].

Post-Fordism has also impacted poverty and unemployment that have exacerbated gender and ethnic inequalities of various types, and in particular, women and minorities have been hit the most, especially after the decline in major state-supported welfare activities that adversely affected women, children, and people of color [4-7]. Indeed, research has also indicated that despite adequate educational attainment and technical skills, women across the globe have continued to face occupational discrimination across industries $[15,16]$. Women have economically always contributed to the larger society through paid and unpaid work [17]. Now, even though women have started reaping the benefits of their improved skills and educational attainments by increasing their participation in male-dominated industries, more progress is required to attain gender equity and parity across non-traditional industries so that economic parity can be achieved [2].

\subsection{Global and Local Perspectives on Gendered Economic Inequalities}

Gender differences across occupations and their restricted participation as paid labor in industries has drawn international attention from economists and social scientists in recent times [17-19]. Women continue to be severely underrepresented at almost every level in corporate America, even though their educational attainments have increased significantly over three decades, and despite women's improved shares in post-high school and collegiate-level education over those of men, their participation in some of the traditionally masculine occupations and industries have not changed proportionately [20,21].

Research suggests that women's under/over-representation in specific industries occurs also due to the formal and informal nature of work and their activity spaces, which assigns differential monetary values to activities based on their activity spaces-public versus private $[1,15-17,20,21]$. This occurs because most activities performed by women are completed inside domestic spaces, i.e., in private spaces inside the boundaries of their households, which makes them invisible and undervalued [1,17,20-23]. As such, women's 
activities performed inside the boundaries of their homes largely become undervalued, resonating with the dark side of reproductive and caring activities by women.

Differences across available occupational and employment opportunities also impact the overall income and wellbeing of women (and minorities of sorts) [24-30]. It is well known that in general, the service sectors of the economy are the lowest paid, whereas knowledge-based occupations pay much higher, and women have had historical underrepresentation in these sectors [1,2,8]. Glynn (2018) suggests that by making work hours more flexible, one can make workers more interchangeable, which will help narrow the economic benefits derived out of the rigid work schedule. This will allow women, especially those with kids and other 'for-care' dependents at home, to work fuller hours based on their flexible schedule. Kliff, however, places greater emphasis on increasing women's participation in specific knowledge-based (or creative, in Florida's jargon) professions rather than just focusing on flexible work hours $[27,28]$. In many ways, these scholars suggest multi-layered approaches to narrowing income and wealth gaps across genders.

The United Nations has indicated that women's restricted participation across various industries/occupations has contributed to their restricted economic empowerment which poses serious threats to creating a sustainable and egalitarian society [19,31-35]. By having restricted opportunities for women, the system restricts their access and control over productive resources as well as their knowledge about job-based advertisements and professional networks, work environments and cultures, and finally, their control over their own time and decision-making processes in primarily male-dominated industries [31-35]. It is also important to recognize that education, skill development, and re-skilling over the life course to keep pace with rapid technological and digital transformations and advancements affecting the jobs are critical for women's overall economic health and social wellbeing as these are affected directly and indirectly by their income-generation opportunities and participation in the formal labor market [19,32]. Such differences in opportunities not only impact women's immediate economic wellbeing, but also affect generations to come as the cycles of deprivation continue [10-13,15,16,30-35].

Sadly, though, scholars have also noted that globally, about 2.7 billion women have far lesser choices of jobs compared to men due to cultural, political, and social reasons. Out of 189 economies, 104 countries still prevent women from working in specific types of jobs; in 59 countries, there are no laws to protect women against sexual harassment; and in 18 countries, husbands can still legally prevent their wives from working $[19,32]$. These indeed illustrate the enormously unfavorable power dynamics that are in fact political and the social manifestations of the undue economic disadvantages of women that have been ongoing for a long time.

\subsection{Contextualizing Spatiality in Gendered Economy}

Regarding the spatial distribution of industries/occupations, various scholars have attributed it to the differential levels of human capital resources and/or lack of skill presence across space. Geography plays an important role in innovation processes, and inherently, location shapes the culture of innovations that varies across gender [25]. This is based on Cook \& Gerson's report of the extremely low number of patents from women across STEM disciplines, including the low level of Ph.D. attainment by women in STEM disciplines and the challenges faced by them in scientific innovations [25]. The Silicon Valley and Wall Street have a heavily skewed male workforce, whereas women's underrepresentation across other regions is very low [1,2]. Living and working in these areas influences and shapes women's perceptions of their own work and creativity since their occupations and activities get shaped by the limitations posted by the complex interactions between space/place, culture, and history [36].

In their critique of Richard Florida's creative class thesis, the authors describe the ways in which the new economy is essentially a repackaged version of the old economy that is quite segregated based on gender, race/ethnicity, and class [37]. Labor market practices such as social networking, which requires extensive hours of socializing beyond the work- 
place to find work, have increasingly become an integral part of the new economy [37]. Such an increase in the flexibility and informality of work erodes work-life balance, and with longer work hours, either expected or implied, also comes greater chances of exacerbating gender inequalities. In many societies that are still strung on patriarchal values, many women may find themselves in more precarious and vulnerable situations in a new world that is contextualized by a new/creative economy [37]. Thus, the role of place and space in creating and sustaining multiple dimensions of inequalities is important-be it income, education, housing, crime, poverty, or any other dimension of inequality [38]. The authors thus help us understand how space, spatiality, and culture interact with gender (or race, class, nationality, sexuality, and the like), which becomes a foundation of US socioeconomic inequality.

Yet another dimension of gender-based inequality is the role of authority at workplacea topic heavily researched by sociologists in exploring workplaces [39]. There are numerous factors that impact authority at workplaces that can be experienced differently by people of different genders, races, nationalities, and the like [1,39]. Women often have less authority than men and other minorities (race, class, sexuality, nationality, etc.) compared to white males, and these elements often reproduce cycles of inequalities through generations $[1,35,40]$.

\subsection{Theoretical Framing of Gendered Economic Inequalities}

Regarding differential levels of gendered (or racialized) under/over-representations across industries/occupations, scholars have largely used the Human Capital Theory (HCT), the Neoclassical Economic Theory (NET), the Labor Market Segmentation Theory (LMST), or the Feminist Political Ecology (FEP) to explain the empirical, political economy and the socially constructed processes of creating 'differentiation.' The HCT attributes gender-based (or race-based) concentrations in specific industries and occupations/jobs to the labor supply aspects within the labor market. It is by choice that men or women choose specific jobs based on their overall educational backgrounds and skills that ultimately qualify them for specific occupations/industries and that the labor market is not to be blamed for the uneven gendered clustering across industries [1,2,41].

The NET, on the other hand, attributes pure economic motives of men versus women as the drivers of specific jobs and opportunities and indicates that preferences, prejudice, discrimination, expectations, hopes, insecurities, etc., are exogenous to the labor market. The NET thus completely ignores the complex ways in which the overall socio-economic or historical contexts of gender/population groups might impact their occupational choices. Geographer Anne Bonds, however, has warned against the economic determinism of some of these theories in explaining gendered (or racial/ethnic) dimensions of economic inequalities [42]. She says that by grounding race in economic relations in a way that obscures the connections between processes of racialization and economic practices, one can mask the nuances that go underneath the elements of power dynamics that have historical, cultural, and spatial contexts. In the real world, the overall socio-economic, cultural, historical, and political contexts of people shape their overall experiences and attainment of skills and networks, which eventually determine the opportunities available to them.

The LMST, however, rejects the simplistic linear relationship between gendered/labor market outcomes with their educational skills or experiences; instead, it argues that the labor market has its own succinct set of rules and socially-constructed political economies that are unique to each industry and institution type which make it possible to socially construct and manifest varying degrees of differentiation and discrimination in the labor market to continue and (re)produce [1]. The LMST thus comes closest to critically linking the social construction and subtle discrimination in the labor market with the political economy ideologies captured by the Feminist Political Ecologists' take on explaining the gendered dimensions of discrimination and differentiation. Gender, thus, intersects with major variables such as race/ethnicity, religion, caste, nationality, and the societal power 
dynamics that produce varying levels of labor participation across industries [43-47]. When such differences persist in the larger society, it is almost impossible to fully attain the 17 goals of sustainable economic development, as laid out in the UNDP's Envision-2030 goals, that are critical to attaining gender parity and a just society [32,33,37].

To sum up, based on this overview of empirical and theoretical work focused on gender disparity in economic opportunities, I argue that if the neoclassical economic theory were to hold its ground, why would one notice an over-concentration of specific gender (or races/ethnicities) in specific types of occupations/industries? How might women's assumed roles and responsibilities at home impact their fuller participation toward educational attainments and subsequently job opportunities? How might lack of information sharing about specific labor market opportunities and formal and informal professional networks impact gendered opportunities? While all these require a long series of analytical inquiries, in this paper, I explain one aspect of contemporary genderbased occupational variation across the counties of USA, using a multi-scalar approach to occupation types-an aspect not yet addressed adequately in economic geography scholarship. In doing so, I examine the level of differences in micro-scale occupation types by gender for all major occupations in the USA for which data is available at the NHGIS [48]. I also conduct visual analysis of these patterns, followed by bivariate correlationships between human capital skills, proxied by educational attainments and occupation types for both genders.

\section{Research Design}

This analysis focuses on the 3142 counties of USA, excluding Puerto Rico but including Alaska and the Hawaiian Islands. Counties are used as the scale of analysis to gain local as well as regional/sub-regional spatial perspectives on the gendered dimensions of occupational inequalities, and how might they reflect varying levels of human capital accumulation. I use counties as the scale of analysis for this work because of my focus on the whole country rather than a single metro or a group of metropolises where inter-metro or an intra-metro analysis would have been a preferred scale. Given this paper's focus on gendered dimensions of occupational and educational inequalities, prior work suggests that women, in general, are affected by similar factors manifested due to structural, institutional, historical, and cultural nuances when they live in geographically similar areas/sub-regions $[1,2,36]$. By using counties as a scale to assess educational and occupational patterns, I also contextualize and normalize the status of education and occupation across counties as each county is governed by its own distinct sets of rules and policies that affect each county's men and women almost similarly, until and unless they are outliers in terms of wealth or political power. Having done a significant amount of intra-urban/interurban research in geography and social sciences, I have found that census tracts-usually a proxy for neighborhoods-have been used for fine-scale analysis. In some cases, scholars have also adopted even finer scales of geography - a "micro-neighborhood" - which they define as a cluster of eleven households together, giving them the benefit of a finer analysis than a census tract [49]. There are other works that have used still finer scales of datablock-group data-in computing statistics to examine diversity at the tract-scale, thence proving a very fine scale of intra-urban analysis [50,51]. Thus, while there are potential advantages of using finer scales of data to analyze finer scales of geographies, scholars have also warned us of the disadvantages of using fine-scale data. Given that most data are prepared and made available through estimates, while finer scales of data are very useful in answering pressing questions concerning intra-urban patterns of inequalities, one should also be aware of the very high levels of errors, uncertainties, and missing values as one goes further down into finer scales of geographies [52,53].

Finally, regarding the use of counties as the scale of analysis in this research, it is well known that a large body of regional science and economic geography research primarily focuses on counties, states, countries, and economic sub-regions/regions or continents as scales of analyses, especially when dealing with regional or sub-regional economic 
inequalities or the like $[1,2,8]$. In a recent work on an unrelated topic concerning women, for example, the scholars used data on the availability of abortion clinics for three years2000, 2011, and 2014-to examine the spatial disparities in commute distance to access the nearest abortion clinics by states and by counties [54]. The scholars chose this large of a geographic entity to adjust for the privacy and sensitivity of abortion as an 'act' as well as to obtain an idea of the difficulties pertaining to accessing abortion clinics. Hence, the counties and states became their scale of analysis. Likewise, scholars often use larger geographies to conduct analyses on sensitive issues, such as crime, drugs, prostitution, HIV/AIDSs, and the like, to mask and protect the confidentiality of the target population due to high risks involved [55]. When research on the pandemic of COVID-19 started, almost every quantitative research presenting and mapping the infection rates analyzed them at the scale of countries, states, or counties (when considering infections in the USA, see the cited source link), rather than cities, tracts, or blocks, largely to protect the confidentiality of the population, given the sensitivity of COVID-19 and potential victimization of the infected population [56]. Because of many such issues discussed here, and the fact that county-scale analyses were quite capable of providing me with an overview of regional and sub-regional perspectives on occupation and education, I chose counties as these captured local, specific, nuanced differences better than states, while also masking the tract-scale sensitivity.

In terms of variables analyzed in this paper, I use educational attainment as a proxy for human capital skills whereas occupational categories and sub-categories by gender also comprise the dependent variables. I use five years' (2015-2019) American Community Survey (ACS) estimates data from the Minnesota NHGIS to conduct descriptive analyses of occupational types, followed by the computations of Location Quotients $(L Q)$ by macro and micro-scalar occupations by gender for all counties of the USA [57]. Thereafter, I conduct descriptive statistics of the computed values of the location quotients by gender for five major categories of occupation. This is followed by a detailed share analysis of the 26 sub-categories of occupations by gender. Later, I conduct Pearson's bivariate correlations analysis to examine the degrees of association between human capital variables proxied by educational attainments and the five major categories of occupations for which $L Q$ values are already computed. This helps analyze the strength and direction of association between the two, and if the Human Capital theory might help explain the over/underrepresentation of gender in various types of occupations. To compute $L Q$ values for this analysis, I follow these specifications [57]. A generic equation for location quotient (LQi) for an occupation $i$ in a county can is:

$$
L Q i=((e i / e))((E i / E))
$$

where $e i$ is the employment in occupation $i$ in the local region/county; $e$ is the total employment in the specific occupation in the country; $E i$ is the employment of the gender (male/female) in the specific occupation $i$ at the national level/country; and $E$ is the total employment by adding total employment in all five major occupations taken together in the country.

Later, I also use ArcGIS Pro to map the computed $L Q$ values for five major categories of occupations by gender for a quick visual snapshot of its spatial variation, even though I do not delve much deeper into its descriptive or causal analysis due to the word limitation for this paper (I hope to publish detailed causal analytical work in forthcoming submissions).

\section{Analysis and Findings}

The total population covered in this analysis of 3142 US counties in 2019 (excluding Puerto Rico) is $324,697,795$. Non-Hispanic Whites comprise the largest share $(60.70 \%)$ of all racial/ethnic groups, followed by Hispanics (18.01\%), Blacks (12.31\%), and Asians (5.62\%). Compared to Census 2000, ACS 2015-2019 shows enormous growth in the shares of Hispanics (12.55\% to $18.01 \%)$ and Asians (3.72\% to $5.62 \%$ ) and a significant decline for Whites (69.13\% to 60.70\%) during 2000-2019, although African Americans maintained consistency at approximately $12 \%$ of the total population (table not included). 


\subsection{Gendered Inequalities in Educational Attainment}

Table 1 (A) shows descriptive statistics highlighting gendered disparity in overall levels of educational attainments for major categories of education, whereas Table 1 (B) illustrates these patterns across major fields of specialization by gender.

Table 1. Educational attainment and bachelor's (major) by gender, 25 years and older (share).

\begin{tabular}{|c|c|c|c|c|c|c|c|c|c|c|c|c|}
\hline \multirow{2}{*}{ A. Educational Attainments } & \multicolumn{6}{|c|}{ Males } & \multicolumn{6}{|c|}{ Females } \\
\hline & Mean & Min & $\operatorname{Max}$ & 35 & 50 & 65 & Mean & Min & Max & 35 & 50 & 65 \\
\hline Total Population & 0.49 & 0.41 & 0.72 & 0.48 & 0.49 & 0.49 & 0.51 & 0.28 & 0.59 & 0.51 & 0.51 & 0.52 \\
\hline No Schooling & 0.01 & 0.00 & 0.06 & 0.00 & 0.01 & 0.01 & 0.01 & 0.00 & 0.09 & 0.00 & 0.00 & 0.01 \\
\hline No High School & 0.07 & 0.00 & 0.34 & 0.05 & 0.06 & 0.07 & 0.06 & 0.00 & 0.39 & 0.04 & 0.05 & 0.06 \\
\hline High School Diploma & 0.18 & 0.02 & 0.44 & 0.16 & 0.18 & 0.20 & 0.16 & 0.03 & 0.27 & 0.15 & 0.16 & 0.18 \\
\hline Some College/Associate & 0.14 & 0.04 & 0.28 & 0.13 & 0.14 & 0.15 & 0.17 & 0.01 & 0.32 & 0.16 & 0.17 & 0.18 \\
\hline Bachelor's Degree & 0.07 & 0.00 & 0.25 & 0.05 & 0.06 & 0.07 & 0.08 & 0.00 & 0.20 & 0.06 & 0.07 & 0.08 \\
\hline Master's Degree & 0.02 & 0.00 & 0.15 & 0.02 & 0.02 & 0.03 & 0.03 & 0.00 & 0.14 & 0.03 & 0.03 & 0.04 \\
\hline Professional Degree & 0.01 & 0.00 & 0.06 & 0.00 & 0.01 & 0.01 & 0.01 & 0.00 & 0.04 & 0.00 & 0.00 & 0.01 \\
\hline Doctorate & 0.01 & 0.00 & 0.14 & 0.00 & 0.00 & 0.01 & 0.00 & 0.00 & 0.04 & 0.00 & 0.00 & 0.00 \\
\hline Master's / Above & 0.04 & 0.00 & 0.25 & 0.02 & 0.03 & 0.04 & 0.04 & 0.00 & 0.20 & 0.03 & 0.04 & 0.04 \\
\hline B. Major-BS Degree & \multicolumn{6}{|c|}{ Males } & \multicolumn{6}{|c|}{ Females } \\
\hline Sc./Engineering, & 0.18 & 0.00 & 0.57 & 0.17 & 0.18 & 0.20 & 0.11 & 0.00 & 0.55 & 0.10 & 0.11 & 0.12 \\
\hline Sc./Eng. Related-Field & 0.03 & 0.00 & 0.17 & 0.02 & 0.03 & 0.03 & 0.08 & 0.00 & 0.27 & 0.07 & 0.08 & 0.09 \\
\hline Business & 0.10 & 0.00 & 0.31 & 0.08 & 0.10 & 0.11 & 0.08 & 0.00 & 0.43 & 0.07 & 0.08 & 0.09 \\
\hline Education & 0.06 & 0.00 & 0.46 & 0.04 & 0.05 & 0.06 & 0.16 & 0.00 & 0.48 & 0.14 & 0.16 & 0.18 \\
\hline Arts/Humanities/Others & 0.09 & 0.00 & 0.75 & 0.08 & 0.09 & 0.10 & 0.11 & 0.00 & 0.43 & 0.10 & 0.11 & 0.12 \\
\hline
\end{tabular}

Note: Shaded cells show higher shares compared to the other gender.

On an average, the median level of educational attainments in all categories (no high school diploma, high school diploma, some college/associate degree, bachelor's, master's, professional or doctoral degrees) is relatively higher for females compared to males; the same holds true across the 65th percentile values at all educational levels, with females faring relatively better than males. However, the maximum values are better for males across most educational categories, except some college/associate where women are slightly better off ( 0.324 for females versus 0.282 for males).

Most interesting to note is the significant variation across genders for majors/fields of study during their bachelor's degree, with males faring better than females in the disciplines of science/engineering and business (see median values in Table 1 (B)) whereas females do better in science/engineering related fields, and significantly better in education and arts/humanities/other majors. Despite equal or higher levels of educational attainment, women's participation in major occupations that are better paid than others are far lower compared to males (explained below in Sections 4.2-4.4). Sadly, despite almost equitable levels of educational attainments across categories, the level to which these skills do not translate into occupational attainments and the consequential loss of income/monetary gains for females is concerning. This largely speaks of the nuanced influence of culture and historical political economy in creating gendered disparities-a finding well-illustrated in another mixed-methods qualitative work [36]. This poses an important question that needs further detailed investigation at the national level.

\subsection{Descriptive Statistical Analysis of Location Quotients by Gender by Occupation, 2019}

The descriptive statistics of computed values of location quotients ( $L Q s)$ for both genders across five major categories of occupations illustrates interesting dynamics about the US labor market (Table 2). The median and maximum values for LQs for males in specific occupations such as management are: 0.357 vs. 1.055 for males; in natural resources, construction, and maintenance: 1.302 vs. 5.19; and in production, transportation, and material moving: 0.997 vs. 4.806 , respectively. For females, however, the median and maximum values of $L Q s$ occur for service-occupations ( 0.607 vs. 1.696$)$ and sales/office 
(0.635 vs. 1.344$)$, respectively, and even in management, the median value for females is 0.459 , which is slightly higher than for males.

Table 2. Descriptive statistics for location quotient values by occupation by gender, 2019.

\begin{tabular}{lrrrrrrr}
\hline LQ-2019, Males & Mean & Range & Min. & Max & 35th & 50th & 65th \\
\hline Management, Business, Science, and Arts & 0.375 & 0.971 & 0.084 & 1.055 & 0.321 & 0.357 & 0.397 \\
Service & 0.405 & 1.270 & 0.000 & 1.270 & 0.354 & 0.394 & 0.434 \\
Sales \& Office & 0.299 & 0.685 & 0.000 & 0.685 & 0.271 & 0.300 & 0.330 \\
Nat-Resources, Construc. and Maintenance & 1.347 & 5.191 & 0.000 & 5.191 & 1.148 & 1.302 & 1.465 \\
Product Transport and Material Moving & 0.991 & 4.807 & 0.000 & 4.807 & 0.847 & 0.992 & 1.120 \\
\hline LQ-2019, Females & Mean & Range & Min. & Max & 35 th & 50 th & 65 th \\
\hline Management, Business, Science, and Arts & 0.464 & 0.898 & 0.000 & 0.898 & 0.432 & 0.459 & 0.487 \\
Service & 0.609 & 1.696 & 0.000 & 1.696 & 0.558 & 0.601 & 0.644 \\
Sales \& Office & 0.634 & 0.992 & 0.142 & 1.134 & 0.604 & 0.635 & 0.664 \\
Nat-Resources, Construc. and Maintenance & 0.074 & 1.325 & 0.000 & 1.325 & 0.040 & 0.055 & 0.071 \\
Product Transport and Material Moving & 0.289 & 1.075 & 0.000 & 1.075 & 0.206 & 0.256 & 0.319 \\
\hline
\end{tabular}

Note: Shaded cells represent the occupations by gender that are far greater than the opposite sex.

The most interesting aspect of the $L Q$ values is the enormously high/maximum values of 5.19 and 4.81 for males in natural resources/construction/maintenance and production/transportation/material-moving compared to females' LQs (Table 2). These occupations, historically and culturally, are considered 'masculine'. In service and sales/office occupations, however, the over-representation of females persists-occupations that have traditionally been perceived as 'feminine.' These speak to the unique dynamism of gendered over/under-representation in specific occupations that are manifestations of historical, cultural, and regional/sub-regional contexts. These occupations offer lower remunerations compared to others, which largely explains females' over-representation along with their implied relative lower economic wellbeing. Such observations have been found by researchers earlier as well, wherein feminine occupations were associated with lower wages/earnings [1,26,30].

However, in management, business, science, and arts occupations, even though the median and maximum values of $L Q$ for females are slightly higher than males, the difference is insignificant; this could be masking a situation wherein several types of jobs within this larger category of management, business, science and arts occupations might be employing women that are relatively at the level of clerical/basic administrative positions, associated with far lower wages than the typical masculine corporate-level wellpaid managerial level positions, resonating with prior research [26,30]. This analysis also necessitates fine-scale further investigations into occupations, with a detailed analysis of occupation types. The ACS data used here provides data on 26 sub-categories of occupation within the five major occupation types discussed above, and I provide a detailed share analysis into gendered dimensions of occupational disparity across the country for these 26 sub-categories for better understanding into the contemporary status of women's occupations in the USA (see Section 4.3). However, even for major occupational categories, this analysis speaks volumes about gender-based divisions of labor and lack of female participation in occupations that have traditionally been male-dominated, whereas women are still over-represented in the feminine occupations associated with lower pay scales. These trends of masculine versus feminine disparity in occupational representation are well-illustrated in the descriptive statistical overview by gender across the whole country.

\subsection{A National Overview of Gender Disparity in Occupation Types in 2019}

Given that this paper focuses on critically analyzing the multiple dimensions of gendered economic inequalities, these detailed sub-occupation-based employment numbers and shares provide an interesting overview of both men and women. As noted in Table 3, shaded occupations are the five major categories of occupations for which major occupation-based location quotients have been computed and they are discussed below 
in the following section. Each of these occupation types comprise further occupational sub-categories, detailed in the table in 26 sub-categories. Accordingly, the shares of women in each occupational category have been computed for within-gender and nation-wide variations. Women comprise $47.49 \%$ of the total employed $(154,842,185)$ civilians nation-wide (16 years and above), whereas men comprise $52.51 \%$ of the total.

Table 3. Detailed employment shares by categories of occupations by gender, nationwide and among-gender, 2019 (employed civilians, 16 years and older).

\begin{tabular}{|c|c|c|c|c|c|c|c|}
\hline \multirow[t]{2}{*}{$\begin{array}{l}\text { Occupation Categories with Sub-Categories } \\
\text { (Employment, 2019) }\end{array}$} & \multicolumn{2}{|c|}{ Employed } & \multicolumn{2}{|c|}{$\begin{array}{c}\text { Shr, } \\
\text { Occup-Types }\end{array}$} & \multicolumn{2}{|c|}{$\begin{array}{l}\text { Nationwide Shr, } \\
\text { Occup-Types }\end{array}$} & \multirow[t]{2}{*}{$\begin{array}{c}\text { ML-FL } \\
\text { Difference }\end{array}$} \\
\hline & ML & FL & ML & FL & ML & FL & \\
\hline Total Civilians Empld. (16 Years and Older) & $81,305,624$ & $73,536,561$ & NA & NA & 0.525 & 0.475 & $7,769,063$ \\
\hline Managemnt, Business, Science \& Arts Occup. & $28,273,415$ & $31,373,868$ & 0.348 & 0.427 & 0.183 & 0.203 & $-310,0453$ \\
\hline Management, business, and financial & $13,225,992$ & $10,881,370$ & 0.163 & 0.148 & 0.085 & 0.070 & $2,344,622$ \\
\hline Management occupations & $9,422,247$ & $6,388,548$ & 0.116 & 0.087 & 0.061 & 0.041 & $3,033,699$ \\
\hline Business and financial operations & $3,803,745$ & $4,492,822$ & 0.047 & 0.061 & 0.025 & 0.029 & $-689,077$ \\
\hline Computer, engineering, and science & $6,848,123$ & $2,420,403$ & 0.084 & 0.033 & 0.044 & 0.016 & $4,427,720$ \\
\hline Computer and mathematical occupations & $3,577,083$ & $1,264,236$ & 0.044 & 0.017 & 0.023 & 0.008 & $2,312,847$ \\
\hline Architecture and engineering occupations & $2,486,105$ & 460,457 & 0.031 & 0.006 & 0.016 & 0.003 & $2,025,648$ \\
\hline Life, physical, and social science occupations & 784,935 & 695,710 & 0.010 & 0.010 & 0.005 & 0.005 & 89,225 \\
\hline $\begin{array}{l}\text { Education, legal, community service, arts, and media } \\
\text { occupations }\end{array}$ & $5,889,127$ & $11,051,160$ & 0.072 & 0.150 & 0.038 & 0.071 & $-5,162,033$ \\
\hline Community and social service & 924,974 & $1,783,615$ & 0.011 & 0.024 & 0.006 & 0.012 & $-858,641$ \\
\hline Legal & 832,889 & 884,521 & 0.010 & 0.012 & 0.005 & 0.006 & $-51,632$ \\
\hline Educational instruction and library occupations & $2,527,118$ & $6,855,907$ & 0.031 & 0.093 & 0.016 & 0.044 & $-4,328,789$ \\
\hline Arts, design, entertainment, sports, and media & $1,604,146$ & $1,527,117$ & 0.020 & 0.021 & 0.010 & 0.010 & 77029 \\
\hline Healthcare practitioners and technical occupations & $2,310,173$ & $7,020,935$ & 0.028 & 0.096 & 0.015 & 0.045 & $-4,710,762$ \\
\hline $\begin{array}{l}\text { Diagns., treating practitioners, and other technical } \\
\text { occupations }\end{array}$ & $1,621,423$ & $4,694,524$ & 0.020 & 0.064 & 0.011 & 0.030 & $-3,073,101$ \\
\hline Health technologists and technicians & 688,750 & $2,326,411$ & 0.009 & 0.032 & 0.004 & 0.015 & $-1,637,661$ \\
\hline Service Occupations & $11,935,283$ & $1,5554,218$ & 0.147 & 0.212 & 0.077 & 0.101 & $-3,618,935$ \\
\hline Service: Healthcare support & 731,643 & $4,326,576$ & 0.009 & 0.059 & 0.005 & 0.028 & $-3,594,933$ \\
\hline Service: Protective service & $2,556,473$ & 744,216 & 0.031 & 0.010 & 0.017 & 0.005 & $1,812,257$ \\
\hline $\begin{array}{l}\text { Protective-Firefighting prevention and other } \\
\text { protective service workers including supervisors }\end{array}$ & $1,363,410$ & 453,308 & 0.017 & 0.006 & 0.009 & 0.003 & 910,102 \\
\hline Protective-Law enforcement workers and supervisors & $1,193,063$ & 290,908 & 0.015 & 0.004 & 0.008 & 0.002 & 902,155 \\
\hline Serv.: Food preparation and serving- related occupations & $4,081,422$ & $4,793,042$ & 0.050 & 0.065 & 0.026 & 0.031 & $-711,620$ \\
\hline Serv.: Building, ground cleaning, and maintn. occupations & $3,507,727$ & $2,394,209$ & 0.043 & 0.033 & 0.023 & 0.016 & $1,113,518$ \\
\hline Serv.: Personal care and service occup. & $1,058,018$ & $3,296,175$ & 0.013 & 0.045 & 0.007 & 0.021 & $-2,238,157$ \\
\hline Sales and Office Occupations & $12,415,204$ & $21,076,422$ & 0.153 & 0.287 & 0.080 & 0.136 & $-8,661,218$ \\
\hline Sales-Sales and related occup. & $7,903,646$ & $7,913,737$ & 0.097 & 0.108 & 0.051 & 0.051 & $-10,091$ \\
\hline Sales-Office and admin. support & $4,511,558$ & $13,162,685$ & 0.056 & 0.179 & 0.029 & 0.085 & $-8,651,127$ \\
\hline $\begin{array}{l}\text { Natural Resources, Construction, and Maintenance } \\
\text { Occupations }\end{array}$ & $13,039,229$ & 674,567 & 0.160 & 0.009 & 0.084 & 0.004 & $1,2364,662$ \\
\hline Farming, fishing, and forestry occupations & 801,561 & 245,548 & 0.010 & 0.003 & 0.005 & 0.002 & 556,013 \\
\hline Construction and extraction occupations & $7,645,657$ & 246,227 & 0.094 & 0.003 & 0.049 & 0.002 & $7,399,430$ \\
\hline Installation, maintenance, and repair occupations & 459,2011 & 182,792 & 0.057 & 0.003 & 0.030 & 0.001 & $4,409,219$ \\
\hline $\begin{array}{l}\text { Production, Transportation, \& Material Moving } \\
\text { Occupations }\end{array}$ & $15,642,493$ & $4,857,486$ & 0.192 & 0.066 & 0.101 & 0.031 & $10,785,007$ \\
\hline Production occupations & $6,317,243$ & $2,544,573$ & 0.078 & 0.035 & 0.041 & 0.016 & $3,772,670$ \\
\hline Transportation occupations & $5,038,937$ & 841,180 & 0.062 & 0.011 & 0.033 & 0.005 & $4,197,757$ \\
\hline Material moving occupations & $4,286,313$ & $1,471,733$ & 0.053 & 0.020 & 0.028 & 0.010 & $2,814,580$ \\
\hline Total Employed in All Occupation Categories, 2019 & & & & 2,185 & & & \\
\hline
\end{tabular}

Note: Shaded categories are the five major categories of occupations, bolded and italics are sub-categories in each major category; bolded and italics numbers are occupations with female share less than $5 \%$, and shaded boxes represent occupations where females occupy more than $10 \%$ of total employment nationally.

Concerning the shares of male versus female in each occupation type nationally, women are represented in large shares (I use above 10 percent as a cut-off) in management/business/science/arts occupations (20.26\%), followed by sales/office (13.61\%), followed by service occupations (10.05\%). While the nationwide figure for management-type occupational employment may sound optimistic, when breaking this major category by its 
various sub-occupation types, in many occupations that are clubbed together in this category, women's share is far less than $5 \%$ (see Table 3). Their nationwide share in specific occupation types is quite alarming, with management at $4.13 \%$, business / financial at $2.9 \%$, computer $/$ mathematical at $0.82 \%$, architecture/engineering at $0.3 \%$, and life/physical/social sciences at $0.45 \%$ only.

The education/legal/community-service/arts/media occupation category fares slightly better, comprising $7.14 \%$ of the national share. However, it is no surprise that women are overly represented in sales/service occupations that are largely associated with lower wages. When analyzing the differential shares of occupations among the same gender, it is interesting that in 2019, women's share is still the largest in sales/office (28.66\%), followed by service (21.15\%) and education/legal/community-service/arts/media (15.03\%) occupations historically categorized as feminine. Without a doubt, then, the largely defined masculine occupations are still male-dominated, as is obvious from Table 3, with management/business/science/arts occupations comprising $18.26 \%$, followed by production/transportation/material-moving occupations that comprise $10.10 \%$ of the nationwide share. These figures become much more masculine when data suggests that $34.77 \%$ of all employed civilian males are employed in management/business/science/arts occupations, with management occupations taking away a large $11.59 \%$ of all civilian males; the next major employments for males (out of all males nationwide) include production/transportation/ material-moving (19.24\%), followed by natural-resources/construction/maintenance (16.04\%), sales/office (15.27\%), and service occupations (14.68\%).

Further insights into each occupation type illustrate detailed patterns for sub-categories of occupations. When examining the occupations where females exceed males nationwide, the greatest winners are sales/office $(-8,661,218)$, followed by education/legal/communityservice/arts/media $(-5,162,033)$, followed by healthcare-practitioners/technical $(-4,710,762)$ and service $(-3,618,935)$. This introspection suggests feminization of gendered activities that have traditionally been occupied by women and their eventual economic impacts on women due to lower financial gains through wages/salaries [1,26]. While it would be an interesting task to conduct a timeseries analysis of these patterns, it is no doubt that the broader pattern of women's employment in largely service/tertiary sectors of the economy remain relatively strong. Sadly, women's engagement in science/engineering and related occupations remains alarmingly low, echoing the fact that there needs to be policy-based interventions to advance women in STEM education in this country. These patterns also highlight the major occupations women are attracted to, either voluntarily or involuntarily, and how some of these might relate with long-held traditional, societal, and cultural inertias of beliefs that prohibit women from taking different pathways toward self-improvement, either through investing in their educational attainment, or through majoring in professional/science disciplines, or through pursuing higher education such as master's, doctorates, or professional degrees that could make them more productive and competitive and equip them with better negotiation power in a presumably fair labor market.

\subsection{Spatial Patterns of Gendered Occupation in US Counties, 2019}

While a fuller explanation of the spatial distribution patterns and processes of occupational representations by gender could be an interesting study in itself, especially when one is interested in digging deeper into its relational aspects with space/place, sub-regionsbased demography, socio-economic status, culture, history, and its contextual political economy, Figure 1 does provide a quick overview of the spatiality of gendered dimensions of occupational patterns in 2019. As expected, some of the most masculine occupations have very high values of location quotients (over-representations) that are region-specific, whereas females generally represent an average distribution pattern across the whole country, especially in blue-collar occupations. 


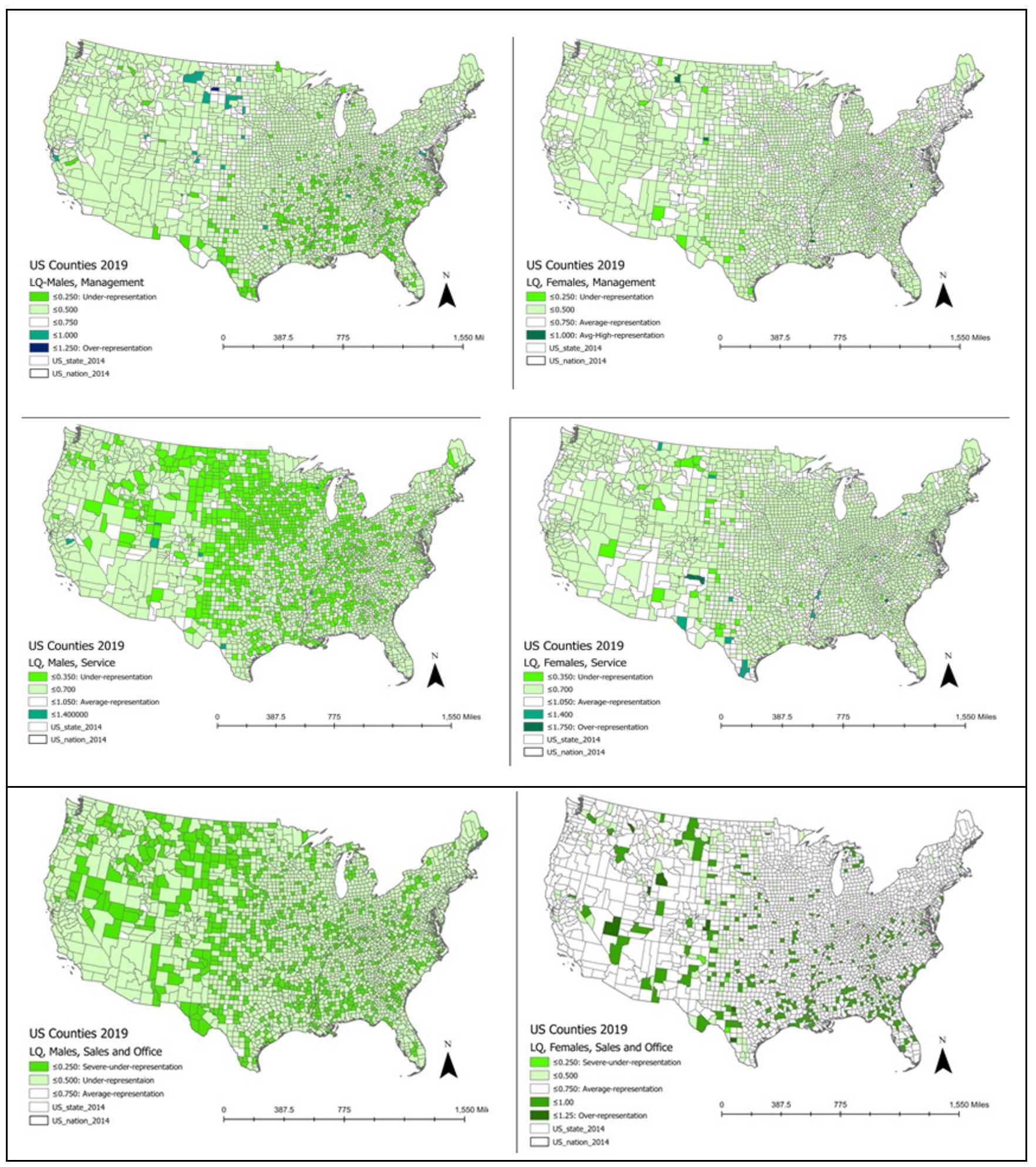

Figure 1. Cont. 


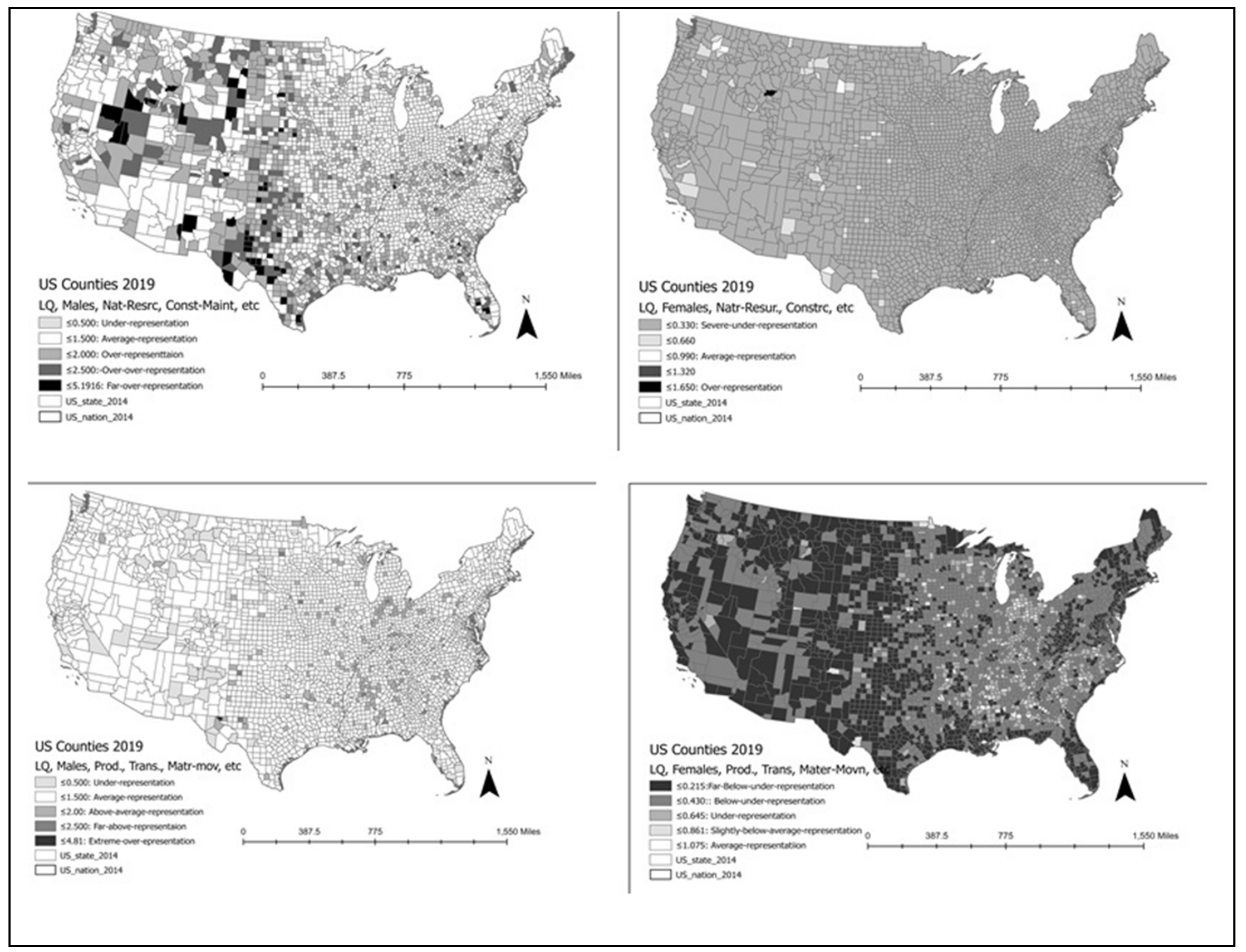

Figure 1. Location quotient maps for five categories of occupations by gender, 2019.

In natural resources, construction, etc., females are severely under-represented throughout the nation, whereas males have quite interesting spatial patterns with the most overrepresenting counties obtaining $L Q$ values of 5.19 (dark grey colors, 4 th row, Figure 1). In service occupations (2nd row in Figure 1), males exhibit a wide variety of spatial patterns, ranging from a minimum of 0.35 to a maximum of 1.4 ; females, on the other hand, go as high as 1.75 in service, and some of those counties are along the southwest borders in Texas. Females are severely under-represented in production almost all over the country (5th row, right side, Figure 1). In management, however, females illustrate below-average to severe under-representation (1st row, right side, Figure 1). This broad overview suggests that perhaps a micro-scale analysis of occupational sub-categories could be more meaningful to dissect nuanced causes across regions and sub-regions. However, due to word restrictions for this paper, I limit myself to a simplistic visual presentation of gendered spatial disparity in occupations across US counties.

\subsection{Relational Contexts in Educational Attainment and Gendered Occupations}

Finally, to obtain an insight into the role of the gendered nature of human capital skills in occupational engagement by gender, a Pearson's bivariate correlations analysis suggests major patterns (Table 4). For both genders, in general, those with lower educational attainments (high school diplomas, no high school diplomas and/or no schooling at all) have a negative association with $L Q s$ in management-related occupations and strong positive association with natural/construction occupations, though the levels are far greater for 
males than females in these very masculine occupations. The same categories of educational attainment show up much stronger for service occupations for both genders, indicating the strong role of lower human capital skills in low-waged jobs. However, the coefficients do not indicate any gender-based disparities in these educational categories, implying greater parity across genders in the lesser-educated population.

Table 4. Bivariate correlations between location quotients by major occupations by educational attainments by gender (25 years and above).

\begin{tabular}{|c|c|c|c|c|c|c|c|c|c|c|}
\hline \multirow{3}{*}{$\begin{array}{l}\text { Educational Attainment } \\
\text { (Share) }\end{array}$} & \multicolumn{10}{|c|}{ Location Quotients by Occupation Types } \\
\hline & $L Q$-Mng & $L Q$-Ser & $L Q-S 1$ & $L Q-\mathrm{Nat}$ & $L Q$-Prd & $L Q$-Mng & $L Q$-Ser & $L Q-S 1$ & $L Q$-Nat & $L Q-P r d$ \\
\hline & \multicolumn{5}{|c|}{ Males (ML) } & \multicolumn{5}{|c|}{ Females (FL) } \\
\hline ML, Total & -0.028 & $0.130 * *$ & $-0.166^{* *}$ & $0.245^{* *}$ & 0.010 & $-0.150 * *$ & $0.045^{*}$ & $-0.149 * *$ & $0.069 * *$ & $-0.118 * *$ \\
\hline ML, No School & $-0.282 * *$ & $0.076 * *$ & -0.022 & $0.161 * *$ & $0.180^{* *}$ & $-0.247 * *$ & $0.040 *$ & -0.009 & $0.151 * *$ & $0.145^{* *}$ \\
\hline ML, No HS Dip & $-0.535^{* *}$ & $0.110 * *$ & $-0.246^{* *}$ & $0.351 * *$ & $0.333^{* *}$ & $-0.409^{* *}$ & $0.197^{* *}$ & 0.002 & $0.110 * *$ & $0.224^{* *}$ \\
\hline ML, HS Dip & $-0.581 * *$ & $-0.086^{* *}$ & $-0.381 * *$ & $0.337 * *$ & $0.528 * *$ & $-0.417^{* *}$ & $0.169 * *$ & $0.044^{*}$ & 0.024 & 0.295 ** \\
\hline ML, Sm Collg/Assc & $0.175 * *$ & -0.021 & 0.006 & 0.107 ** & $-0.140 * *$ & -0.033 & -0.007 & -0.028 & $0.081^{* *}$ & $-0.192 * *$ \\
\hline ML, BS Degree & $0.770 * *$ & 0.034 & $0.401 * *$ & $-0.409^{* *}$ & $-0.599 * *$ & $0.542 * *$ & $-0.261 * *$ & $-0.097^{* *}$ & $-0.084^{* *}$ & -0.386 ** \\
\hline ML, MS Degree & $0.681 * *$ & $0.109^{* *}$ & $0.365^{* *}$ & $-0.472 * *$ & $-0.546^{* *}$ & $0.577 * *$ & $-0.230 * *$ & $-0.099 * *$ & $-0.150 * *$ & $-0.313^{* *}$ \\
\hline ML, Prof Degree & $0.562 * *$ & $0.113^{* *}$ & $0.322 * *$ & $-0.431^{* *}$ & $-0.475^{* *}$ & $0.514^{* *}$ & $-0.170 * *$ & $-0.074^{* *}$ & $-0.123^{* *}$ & -0.261 ** \\
\hline ML, Doctoral Degree & $0.490 * *$ & $0.114^{* *}$ & 0.206 ** & $-0.375^{* *}$ & $-0.390 * *$ & $0.439 * *$ & $-0.123 * *$ & $-0.100 * *$ & $-0.103^{* *}$ & $-0.217^{* *}$ \\
\hline ML, MS/Abv Degree & $0.692 * *$ & $0.125 * *$ & $0.361 * *$ & $-0.498 * *$ & $-0.560 * *$ & $0.601 * *$ & $-0.218 * *$ & $-0.106^{* *}$ & $-0.151 * *$ & $-0.317 * *$ \\
\hline FL, Total & 0.028 & $-0.130 * *$ & 0.166 ** & $-0.245^{* *}$ & -0.010 & $0.150 * *$ & $-0.045^{*}$ & 0.149 ** & $-0.069 * *$ & $0.118^{* *}$ \\
\hline FL, No School & $-0.205^{* *}$ & $0.077^{* *}$ & 0.014 & $0.098^{* *}$ & $0.120^{* *}$ & $-0.202^{* *}$ & 0.048 ** & -0.014 & $0.166^{* *}$ & $0.117^{* *}$ \\
\hline FL, No HS Dip & $-0.505^{* *}$ & $0.081^{* *}$ & $-0.176^{* *}$ & $0.307^{* *}$ & 0.323 ** & $-0.431 * *$ & $0.186^{* *}$ & 0.016 & $0.106^{* *}$ & $0.274^{* *}$ \\
\hline FL, HS Dip & $-0.574^{* *}$ & $-0.166^{* *}$ & $-0.232^{* *}$ & $0.221 * *$ & $0.557^{* *}$ & $-0.428^{* *}$ & $0.116^{* *}$ & $0.152^{* *}$ & -0.016 & $0.385^{* *}$ \\
\hline FL, Sm Collg/Assc & 0.017 & $-0.096^{* *}$ & $-0.038 *$ & 0.022 & -0.016 & $-0.048^{* *}$ & $0.059 * *$ & $0.111 * *$ & $0.063 * *$ & -0.029 \\
\hline FL, BS Degree & $0.745^{* *}$ & -0.016 & $0.367^{* *}$ & $-0.412 * *$ & $-0.589^{* *}$ & $0.606^{* *}$ & $-0.242 * *$ & $-0.091^{* *}$ & $-0.097^{* *}$ & $-0.390 * *$ \\
\hline FL, MS Degree & $0.566^{* *}$ & $0.119^{* *}$ & $0.335^{* *}$ & $-0.510 * *$ & $-0.490 * *$ & $0.668^{* *}$ & -0.224 ** & $-0.076^{* *}$ & $-0.176^{* *}$ & $-0.267 * *$ \\
\hline FL, Prof Degree & $0.472 * *$ & $0.112 * *$ & $0.293^{* *}$ & $-0.425 * *$ & $-0.410^{* *}$ & $0.539 * *$ & $-0.204^{* *}$ & $-0.085 * *$ & $-0.128 * *$ & $-0.184^{* *}$ \\
\hline FL, Doctoral Degree & $0.500^{* *}$ & $0.096^{* *}$ & $0.246^{* *}$ & $-0.412 * *$ & $-0.414^{* *}$ & 0.520 ** & $-0.146^{* *}$ & $-0.114^{* *}$ & $-0.104^{* *}$ & $-0.218^{* *}$ \\
\hline FL, MS/Abv Degree & $0.593^{* *}$ & $0.126^{* *}$ & $0.345^{* *}$ & $-0.528 * *$ & $-0.510 * *$ & $0.684^{* *}$ & $-0.229 * *$ & $-0.091 * *$ & $-0.172 * *$ & $-0.269 * *$ \\
\hline \multicolumn{11}{|c|}{ Male/female ratios in bachelor's degree major fields across various categories by age groups } \\
\hline BS-Total, 25 Yrs/Abv. & $0.329 * *$ & $0.097 * *$ & $0.139 * *$ & -0.004 & $-0.275^{* *}$ & $-0.063^{* *}$ & $-0.058 * *$ & $-0.037 *$ & $0.054^{* *}$ & $-0.159 * *$ \\
\hline $\mathrm{SC} / \mathrm{ENG}, 25-64$ & $0.065 * *$ & $-0.148 * *$ & $-0.109 * *$ & $0.146^{* *}$ & 0.036 * & $-0.116^{* *}$ & 0.019 & $-0.072 * *$ & $0.053 * *$ & -0.014 \\
\hline $\mathrm{SC} / \mathrm{ENG},>65$ & $-0.048^{*}$ & $-0.091 * *$ & $-0.116^{* *}$ & $0.121 * *$ & $0.105^{* *}$ & $-0.132 * *$ & 0.001 & 0.006 & 0.027 & $0.049^{* *}$ \\
\hline SC/ENG/Rld-Fld, 25-64 & $0.055^{* *}$ & 0.029 & 0.016 & $0.040 *$ & $-0.051^{* *}$ & $-0.041 *$ & 0.013 & $-0.055^{* *}$ & 0.016 & -0.030 \\
\hline SC/ENG / Rld-Fld, $>65$ & $-0.050 * *$ & 0.034 & -0.003 & $0.066^{* *}$ & 0.015 & $-0.071 * *$ & 0.026 & -0.005 & 0.003 & 0.011 \\
\hline BSN, 25-64 & 0.017 & 0.019 & 0.030 & $0.062 * *$ & -0.024 & -0.026 & $-0.065^{* *}$ & 0.006 & -0.002 & -0.035 \\
\hline $\mathrm{BSN}^{\prime}>65$ & $-0.041^{*}$ & $-0.043^{*}$ & -0.017 & 0.017 & $0.087^{* *}$ & $-0.041 *$ & $-0.045^{*}$ & -0.006 & -0.001 & $0.052 * *$ \\
\hline EDU, 25-64 & $0.066^{* *}$ & -0.013 & $-0.048^{* *}$ & $0.043 *$ & -0.037 * & $-0.065^{* *}$ & $0.089 * *$ & $-0.082 * *$ & 0.012 & -0.009 \\
\hline EDU, $>65$ & $-0.049 * *$ & 0.037 * & $-0.107^{* *}$ & $0.099 * *$ & $0.041 *$ & $-0.083^{* *}$ & 0.030 & -0.011 & 0.033 & -0.023 \\
\hline $\mathrm{ART} / \mathrm{Hm} / \mathrm{Ot}, 25-64$ & $-0.041 *$ & $0.054^{* *}$ & $-0.092^{* *}$ & $0.081 * *$ & 0.041 * & $-0.130 * *$ & 0.029 & 0.008 & 0.020 & 0.024 \\
\hline Art $/ \mathrm{Hm} / \mathrm{Ot},>65$ & $-0.089 * *$ & -0.021 & $-0.039 *$ & $0.086^{* *}$ & $0.084^{* *}$ & $-0.095^{* *}$ & 0.009 & 0.005 & -0.008 & $0.047^{* *}$ \\
\hline
\end{tabular}

Notes: $L Q$-Mng: $L Q$-Management, Business, Science, and Arts; $L Q$-Ser: $L Q$-Service; $L Q$-Sl: $L Q$-Sales \& Office; $L Q$-Nat: $L Q$-Natural Resources, Construction, and Maintenance); $L Q$-Prd: $L Q$-Production, Transportation, and Material Moving; Education acronymns: SC/ENG = science and engineering; SC/ENG/Rld-Fld = science \& engineering related-field; BSN = business; EDU = education; Art $/ \mathrm{Hm} / \mathrm{Ot}=\mathrm{Arts}$, humanities, and others. ${ }^{* *}$. Correlation is significant at the 0.01 level (2-tailed) \& *. Correlation is significant at the 0.05 level (2-tailed).

As educational attainments increase, males do far better in managerial occupations compared to females, even with some college/associate degrees, indicating some type of educational premium disadvantage for females. With bachelor's degrees, both genders have similar relationships with various occupations (positive with managerial occupations and negative with blue-collar occupations-natural resources, production, construction, etc.), although the coefficients are far stronger for males than females. In sales occupations, however, males have a stronger positive association compared to females, who have a negative association. At the broader category of master's and above, males and females both have similar types of associations across almost all five occupation types, even though coefficients are higher for males in management $\left(0.692^{*}\right.$ vs. $\left.0.601^{*}\right)$. Females, however, have a negative association with service and sales-both tertiary occupations, and in natural resources-a blue-collar occupation, when they have achieved higher education. This reaffirms the idea that with improvement of human capital skills, gender disparity and the nature of occupational patterns do change with time. Thus, women with master's education and above have negative r-values with sales and services-traditionally perceived as the feminine - suggesting change and progress in the desired direction toward achieving greater occupational parity. Here, higher education seems to have a premium payoff for females. 
A quick overview of the correlation coefficients for major fields of bachelor's degrees, however, points to a rather dark side of societal reality. Females have significant and negative associations across all occupations except service, especially when one looks at those related with science/engineering-related disciplines. This suggests that there is either a lack of females specializing in these fields of education, or alternatively, despite their degrees, women prefer to or are unable to attain success in these four types of occupations. The real cause needs further exploration, which is beyond the scope of this analysis. Likewise, those specializing in education or arts/humanities, etc., seemingly have a negative association with managerial occupations for females, and a positive association with service sectors. Males have positive associations with managerial and other masculine occupations, although ageing comes into play, with r-values becoming negative for those aged $>65$ years.

\section{Conclusions and Policy Implications}

This detailed analysis of the gendered dimensions of occupational disparity illustrates various ways in which females face a relative disadvantage compared to males in almost all major occupation types. Regardless of educational attainments, women are unable to acquire the expected levels of participation in occupations that have traditionally been perceived as masculine, and this inherently contributes to lower earnings potentials for females compared to their male counterparts-a concern already established by prior research [26-30]. Even though we are in 2021, this analysis suggests that in 2019, women's largest shares of employment were still limited to sales/office, followed by service and education/legal/community-service/arts/media occupations that have historically been perceived as feminine. Without a doubt, then, the largely defined masculine occupations are still male-dominated. These patterns also suggest feminization of specific occupations that have traditionally been performed by women for ages and their consequential limitations toward limited financial gains. However, in some cases, females do seem to reap the premiums of higher education, as was obvious for those with master's degrees and above.

This analysis also suggests that for those with lower levels of educational attainment, there is not much variation in occupation types, with males and female generally engaging in the age-old traditional masculine versus feminine activities. However, one would assume that educational attainment must provide premiums in terms of economic and occupational equity and parity. This analysis somehow suggests declining premiums for educational attainments, except in some specific types of education. With a gain in education, males do relatively better in managerial occupations that are traditionally associated with a higher pay structure, and this holds especially true for those with some college/associate degree, with males reaping far higher premiums than females.

Interestingly, this analysis also finds that the educational category where the gain in occupational patterns stays the most equitable is those with a bachelor's degree. In this category (bachelor's), both genders have similar types of association-positive for both genders with managerial occupations and negative for both genders with most blue-collar occupations (natural resources, production, and construction), although the coefficients are higher for males than females, reflecting that the benefits of educational attainments are reaped better by males than females, even though females are gaining parity in the right direction as well. However, females do suffer from an educational premium comparative disadvantage, with females gaining relatively less compared to men.

This analysis, however, also shows some rays of hope and progress. On the brighter side, for those with a master's education and above, males and females both exhibited similar types of association across almost all five major occupation types, even though the coefficients loaded much higher for males in managerial occupations compared to females. For females with master's education and above, their association with service/sales and natural resources (primarily blue-collar and low-paying service occupations) were negative.

Women have far lower representation is science/engineering and related educational attainments, which could be contributory factors toward occupational disparity. Sadly, 
women's engagement in science/engineering and related occupation types remains alarmingly low, echoing a critical need for policy-based interventions to promote women in STEM education in this country. Women are forced, either voluntarily or involuntarily, to engage in occupations that are traditionally deemed fit for them by long-held cultural beliefs and patriarchally-created inertias that prohibit women from taking different pathways toward self-improvement, either through improving their educational attainment, through majoring in professional/science disciplines, and/or by pursuing higher education such as master's, doctorates, or professional degrees that could enable them to command better and more equitable occupational opportunities.

Finally, this analysis concludes that with higher education and skills development, the nature of labor market engagement will change, which will eventually create gender economic parity. This must comprise an important strategy for policy makers so that the education and skill development of women, including focused interventions for women in STEM disciplines, can be enforced. By increasing women's education and human capital skills, one can contribute toward their economic empowerment which will create a more inclusive, just, and economically-sustainable society as well as greater gender parity [26-30,33]. As the saying goes, "You educate a man, you educate an individual; you educate a woman, you educate an entire generation." This must become the mantra for attaining gender economic parity in the US and in other parts of the world. This is the only way toward attaining the goals of sustainable economic development, as laid out in the United Nation's 17 goals of sustainable development [33].

Funding: This research received no external funding.

Institutional Review Board Statement: Not applicable.

Informed Consent Statement: Not applicable.

Data Availability Statement: This research was conducted using publicly available Census data and the author has no data available for sharing.

Conflicts of Interest: The author declares no conflict of interest.

\section{References}

1. Coe, N.; Kelly, M.; Philip, F.; Henry, Y.W.C. Economic Geography: A Contemporary Introduction; Coe, N.M., Kelly, P.F., Yeung, H.W.C., Eds.; Blackwell Oxford: Oxford, UK, 2012.

2. Sharma, M. Gender Disparity and Economy in US Counties: Change and Continuity, 2000-2017. In Gender Inequalities: GIS Approaches to Gender; Ozdenerol, E., Ed.; CPC Press: Abingdon, UK, 2020; pp. 73-96.

3. Kearney, M.S. Testimony before the joint economic committee: Income inequality in the United States. JEC Compos. 2014, 1-10. Available online: https:/ / www.brookings.edu/wp-content/uploads/2016/06/16-income-inequality-in-america-kearney-1.pdf (accessed on 30 March 2021).

4. Bakshi, P.; Goodwin, M.; Painter, J.; Southern, A. Gender, race, and class in the local welfare state: Moving beyond regulation theory in analysing the transition from Fordism. Environ. Plan. A 1995, 27, 1539-1554. [CrossRef]

5. Brenner, N. Decoding the newest "metropolitan regionalism" in the USA: A critical overview. Cities 2002, 19, 3-21. [CrossRef]

6. Gartman, D. Postmodernism; or, the cultural logic of post-Fordism? Sociol. Q. 1998, 39, 119-137. [CrossRef]

7. Walks, A. The social ecology of the post-Fordist/global city? Economic restructuring and socio-spatial polarization in the Toronto urban region. Urban Stud. 2001, 38, 407-447. [CrossRef]

8. Florida, R.; Mellander, C. The geography of inequality: Difference and determinants of wage and income inequality across US metros. Reg. Stud. 2014, 50, 79-92. [CrossRef]

9. Moore, J. Documentary, Roger \& Me. 1989. Available online: https:/ /www.youtube.com/watch?v5L8jhqrQRhrY (accessed on 30 March 2021).

10. Sassen, S. Cities in a World Economy; Sage: Thousand Oaks, CA, USA, 1994.

11. Autor, D.; Katzl, F.; Krueger, A. Computing inequality: Have computers changed the labor market? Q. J. Econ. 1998, 113, 1169-1213. [CrossRef]

12. Autor, D.; Levy, F.; Murnaner, R. The skill content of recent technological change: An empirical exploration. Q. J. Econ. 2003, 118, 1279-1333. [CrossRef]

13. Autor, D.; Katzl, F.; Kearney, M. The Polarization of the U.S. Labor Market; NBER Working Paper Series No. 11986; National Bureau of Economic Research Papers: Cambridge, MA, USA, 2006; Available online: http:/ /www.nber.org/papers/w11986 (accessed on 1 June 2017). 
14. Chakravorty, S. Urban inequality revisited: The determinants of income distribution in U.S. metropolitan areas. Urban Aff. Rev. 1996, 31, 759-777. [CrossRef]

15. Quick Take: Women in Male-Dominated Industries and Occupations. 2018. Available online: https://www.catalyst.org/research/ women-in-male-dominated-industries-and-occupations/ (accessed on 8 May 2019).

16. Bureau of Labor Statistics. Labor Force Statistics from the Current Population Survey. Employed Persons by Detailed Industry, Sex, Race, and Hispanic or Latino Ethnicity. Available online: https:/ / www.bls.gov/cps/cpsaat11.htm (accessed on 8 June 2019).

17. Islam, F.B.; Sharma, M. Gendered Dimensions of Unpaid Activities: An Empirical Insight into Rural Bangladesh Households. Sustainability 2021, 13, 6670. [CrossRef]

18. Schneebaum, A. Illuminating the Role of Gender in the Economy. In Wirtschaft Neu Denken: Blinde Flecken in der Lehrbuchökonomie; iRights Media: Berlin, Germany, 2016; Available online: http://fgw-nrw.de/fileadmin/user_upload/Blinde_Flecken_der_ Lehrbuchoekonomie_klein.pdf (accessed on 19 July 2019).

19. Whitmore, D.S.; Ryan, N. The 51\%: Driving Growth through Women's Economic Participation; Brookings: Washington, DC, USA, 2017.

20. Krivkovich, A.; Robinson, K.; Starikova, I.; Valentino, R.; Lareina, Y. Women in the Work Place 2017; McKinsey \& Company: New York, NY, USA, 2017; pp. 1-6.

21. McKinsey \& Company. The Power of Parity: How Advancing Women's Equality Can Add $\$ 12$ Trillion to Global Growth. Report. 2015. Available online: https://www.mckinsey.com/ \{\}/media/McKinsey/Featured\%20Insights/Employment $\% 20$ and $\% 20$ Growth/How\%20advancing\%20womens\%20equality\%20can\%20add\%2012\%20trillion\%20to\%20global\%20growth/MGI\%20 Power\%20of\%20parity_Full\%20report_September\%202015.ashx (accessed on 20 July 2019).

22. Landau, K.; Lewis, R. Toward Gender Equality and Inclusivity in Oil, Gas, and Mining. 2018. Available online: https://www. brookings.edu/blog/fixgov/2019/03/29/toward-gender-equality-and-inclusivity-in-oil-gas-and-mining/ (accessed on 20 July 2019).

23. Reeves, R.V.; Venator, J. Policies to Expand Women's Opportunity; Brookings: Washington, DC, USA, 2014.

24. Boushey, H.; Bahn, K. Women's Work-Life Economics; Washington Center for Equitable Growth: Washington, DC, USA, 2020.

25. Cook, L.D.; Gerson, J. The Implications of U.S. Gender and Racial Disparities in Income and Wealth Inequality at Each Stage of the Innovation Process; Issue Brief: Inequality \& Mobility; Washington Center for Equitable Growth: Washington, DC, USA, 2019.

26. Glynn, S.J. Gender Wage Inequality: What We Know and How We Can Fix It; Report; Washington Center for Equitable Growth: Washington, DC, USA, 2018; 64p.

27. Kliff, S. The Truth about the Gender Wage Gap. Vox, 8 September 2017; pp. 1-29.

28. Kliff, S. A Stunning Chart Shows the True Cause of the Gender Wage Gap: The Gender Wage Gap is Really a Childcare Penalty. Vox, 18 February 2018.

29. Schober, T.; Winter-Ebmer, R. Gender Wage Inequality and Economic Growth: Is There Really a Puzzle?-A Comment. World Dev. 2011, 39, 1476-1484. [CrossRef]

30. Washington Center for Equitable Growth. Washington Center Report on Gender Wage Inequality in the United States: Causes and Solutions to Improve Family Well-Being and Economic Growth; Washington Center for Equitable Growth: Washington, DC, USA, 2019.

31. Why Gender Matters in Economy? Available online: https:/ / www.arts.ubc.ca/why-gender-matters-in-economics / (accessed on 2 January 2021).

32. UN Economic Development. Available online: http://www.unwomen.org/en/what-we-do/economic-empowerment/factsand-figures (accessed on 2 January 2021).

33. UNDP Envision 2030 Goal 5, Gender Equality United Nations Enable. Available online: https://www.un.org/development/ desa/disabilities/envision2030-goal5.html (accessed on 31 July 2020).

34. Kabeer, N. Women's Empowerment and Economic Development: A Feminist Critique of Storytelling Practices in "Randomista" Economics. Fem. Econ. 2020, 26, 1-26. [CrossRef]

35. Bayeh, E. The role of empowering women and achieving gender equality to the sustainable development of Ethiopia. Pac. Sci. Rev. B Humanit. Soc. Sci. 2016, 2, 37-42. [CrossRef]

36. Sharma, M. Peoples' Perceptions on Housing Market Elements in Knoxville, Tennessee. Southeast. Geogr. 2014, 54, 137-160. [CrossRef]

37. Leslie, D.; Catungal, J.P. Social Justice and the Creative City: Class, Gender and Racial Inequalities. Geogr. Compass 2012, 6, 111-122. [CrossRef]

38. Galster, G.; Sharkey, P. Spatial Foundations of Inequality: A Conceptual Model and Empirical Overview. RSF Russell Sage Found. J. Soc. Sci. 2017, 3, 1-33. [CrossRef]

39. Smith, R.A. Race, Gender, and Authority in the Workplace: Theory and Research. Annu. Rev. Sociol. 2002, 28, 509-542. [CrossRef]

40. Stainback, K.; Tomaskovic-Devey, D.; Skaggs, S. Organizational Approaches to Inequality: Inertia, Relative Power, and Environments. Annu. Rev. Sociol. 2010, 36, 225-247. [CrossRef]

41. Becker, G.S. Human Capital: A Theoretical and Empirical Analysis, with Special Reference to Education, 3rd ed.; University of Chicago Press: Chicago, IL, USA, 1994; 412p, ISBN 9780226041209.

42. Bonds, A. Racing Economic Geography: The Place of Race in Economic Geography. Geogr. Compass 2013, 7, 398-411. [CrossRef] 
43. Rocheleau, D.; Thomas-Slayter, B.; Wangari, E. Feminist Political Ecology: Global Issues and Local Experiences; CPC Press: London, UK, 1996; Volume 164, ISBN 0415120268.

44. Sultana, F. Gendering Climate Change: Geographical Insights; Taylor and Francis: London, UK, 2014; Volume 66, pp. $372-381$.

45. Nightingale, A. The nature of gender: Work, gender, and environment. Environ. Plan. D Soc. Space 2006, 24, 165-185. [CrossRef]

46. Ross, H. Feminist Political Ecology: Global Issues and Local Experiences. Dianne Rocheleau, Barbara Thomas Slayter and Esther Wangari (eds) London and New York: Routledge, 1996. Reviewed by Helen Ross. J. Political Ecol. 1997, 4, 21. [CrossRef]

47. Mollett, S. Environmental struggles are feminist struggles: Feminist political ecology as development critique. In Feminist Spaces: Gender and Geography in a Global Context; Oberhauser, A.M., Fluri, J.L., Whitson, R., Mollett, S., Eds.; Routledge: New York, NY, USA, 2018; pp. 155-187.

48. Manson, S.; Schroeder, J.; van Riper, D.; Kugler, T.; Ruggles, S. IPUMS National Historical Geographic Information System: Version 15.0 [Dataset]; Integrated Public Use Microdata Series (IPUMS): Minneapolis, MN, USA, 2020. [CrossRef]

49. Hipp, J. "What is the neighbourhood" in neighbourhood satisfaction? Comparing the effects of structural characteristics measured at the micro-neighbourhood and tract levels. Urban Stud. 2010, 47, 2517-2536. [CrossRef]

50. Sharma, M. A Geographic Perspective on Intra-Urban Racial/Ethnic Diversity, Segregation, and Clustering in Knoxville, Tennessee: 1990-2000. Appl. Geogr. 2011, 32, 310-323. [CrossRef]

51. Sharma, M. Diversity in Knoxville: An Applied Perspective. Appl. Geogr. 2013, 42, 140-154. [CrossRef]

52. Jung, P.H.; Thill, J.C.; Issel, M. Spatial autocorrelation and data uncertainty in the American Community Survey: A critique. Int. J. Geogr. Inf. Sci. 2019, 33, 1155-1175. [CrossRef]

53. Spielman, S.E.; Folch, D.; Nagle, N. Patterns and causes of uncertainty in the American Community Survey. Appl. Geogr. 2014, 46, 147-157. [CrossRef] [PubMed]

54. Bearak, J.M.; Burke, K.L.; Jones, R.K. Disparities and change over time in distance women would need to travel to have an abortion in the USA: A spatial analysis. Lancet Public Health 2017, 2, e493-e500. [CrossRef]

55. Ho, A.T.; Cho, W. Government communication effectiveness and satisfaction with police performance: A large-scale survey study. Public Adm. Rev. 2017, 77, 228-239. [CrossRef]

56. WORLD/COUNTRIES/UNITED STATES. Available online: https://www.worldometers.info/coronavirus/country/us / (accessed on 8 April 2021).

57. Moineddin, R.; Beyene, J.; Boyle, E. On the Location Quotient Confidence Interval. Geogr. Anal. 2003, 35, 249-256. [CrossRef] 